\title{
Evaluation of the physico-chemical state of the soil contaminant isolate indigenous bacterial species
}

\author{
Nwankwo CC ${ }^{1}$, John Godson N 2,* and Daodu Bamidele $\mathrm{T}^{3}$ \\ ${ }^{1}$ Department of Microbiology Technology, School of Science Laboratory Technology, University of Port Harcourt. \\ 2 Department of Biochemistry/Chemistry Technology, School of Science Laboratory Technology, University of Port \\ Harcourt. \\ ${ }^{3}$ Department of Science Laboratory Technology, Delta State University of Science and Technology, University of Port \\ Harcourt.
}

GSC Biological and Pharmaceutical Sciences, 2021, 17(02), 139-151

Publication history: Received on 09 October 2021; revised on 17 November 2021; accepted on 19 November 2021

Article DOI: https://doi.org/10.30574/gscbps.2021.17.2.0331

\begin{abstract}
The aim of the study is to isolate indigenous bacterial species which have the ability to degrade crude oil. Samples were collected from an oil polluted site in Ejama-Ebubu Eleme Rivers state. The samples were taken from five spot (A-E), of depth 0-15 (A1- E1) and 15-30 (A2- E2) in sterile polyethylene bags, using appropriate equipment, then taken to the laboratory for analysis, Physicochemical parameters such as $\mathrm{pH}$, nitrate, sulphate, phosphate, total petroleum hydrocarbon (TPH), poly aromatic hydrocarbon (PAH), salinity, temperature, conductivity and heavy metals (iron, zinc, nikel, lead, chromium) were determined, The THB count was determined using the spread plate method on nutrient agar. Soil, sediment and water physicochemical parameters determined indicated that the samples had been exposed to hydrocarbon contamination. The Gram negative bacteria belonging to the genus pseudomonas is the most frequent. Other genera isolated were Nocardia, Micrococcus,Chromobacterium, Burkholdia, Corynebacterium. The study revealed the presence of petroleum hydrocarbons in the Ejama_Ebubu site as well as known genera of hydrocarbon utilizing bacteria. The biases associated with culture-dependent microbial enumeration techniques may limit the full description of the bacterial diversity in Ejama-Ebubu site. From the study, it is concluded that microorganisms that can degrade hydrocarbons are found in oil contaminated soil and can easily be isolated from these contaminated sites, although it is very difficult to work with aromatic hydrocarbons due to their volatility and toxic effects.
\end{abstract}

Keywords: Physiochemical; Microorganisms; Biodegradation; Bacterial

\section{Introduction}

The release of hydrocarbon into soil and water promotes the growth and proliferation of hydrocarbon utilizing microorganisms (HUM), which includes both bacteria and fungi. Incidentally, these hydrocarbon utilizing bacteria (HUB) and hydrocarbon utilizing fungi (HUF) are also the organisms that are responsible for the biodegradation and eventual cleanup of oil spills in our environment Bioremediation, which is accomplished by adding exogenous microbial populations or stimulating indigenous ones, attempts to raise the rates of degradation found naturally to significantly higher rates (Watanabe,2001).

The biodegradation is not a new concept when dealing with oil pollutants, it has been intensively studied in controlled conditions (Chaillan et al., 2004) and in open field experiments (Chaineau et al., 2003; Gogoi et al., 2003), but it has acquired a new significance as an increasingly effective and potentially inexpensive cleanup technology. Its potential contribution as a countermeasure biotechnology for decontamination of oil polluted systems could be enormous.

${ }^{*}$ Corresponding author: John Godson N

Department of Biochemistry/Chemistry Technology, School of Science Laboratory Technology, University of Port Harcourt.

Copyright @ 2021 Author(s) retain the copyright of this article. This article is published under the terms of the Creative Commons Attribution Liscense 4.0. 
Bioremediation using microorganisms of hydrocarbon contaminated site is performed with the help of a diverse group of microorganisms, particularly the indigenous bacteria present in soil (Sebiomo et al., 2010). Bioremediation is emerging as one of the most promising technologies for the removal of petroleum hydrocarbons from the environment. For this, the screening of potential crude oil degrading organisms is one of the key steps (Varjani et al 2013).

Accidental releases of petroleum products are of particular apprehension in the environment. Conventional disposal methods of incineration or burial insecure landfills currently can become prohibitively costly when dealing with large amounts of contaminants. Bioremediation functions basically on biodegradation, which may refer to complete mineralization of organic contaminants into carbon dioxide, water, inorganic compounds, and cell protein or transformation of complex organic contaminants to other simpler organic compounds by biological agents like microorganisms (Nalineekumari et al 2013).

The release of crude oil into the environment can be accidental or deliberately leading to serious pollution problems. Even small releases of petroleum hydrocarbons into aquifers can lead to concentrations of dissolved hydrocarbons far in excess of regulatory limits (Spence etal., 2005). Removal of poly aromatic hydrocarbons (PAHs) from the environment is very difficult due to their high hydrophobicity which increases with increasing molecular weight and this results in higher toxicity and longer persistence in the environment (Chauhan etal 2008). But there are a variety of microorganisms (bacteria and fungi) that are capable of degrading certain PAHs therefore there is a significant interest in studying microorganisms in contaminated sites as a mean for bioremediation (Daaneetal 2001).

Hydrocarbon (HC) are organic compounds which are composed of two main elements-carbon and hydrogen. They also contain small quantities of molecules containing sulphur, nitrogen, metals, oxygen, etc., (Vieira et al., 2007). Petroleum, in Latin means rock oil, which occurs as a dark, sticky, viscous liquid. Petroleum products such as gasoline, kerosene, diesel / fuel oil, crude oil are complex mixture of organic compounds basically of paraffinic, oleifinic and aromatic hydrocarbons (Mittal and Singh, 2009; Singh and Lin, 2008; Vieira et al., 2007).

HCs in crude petroleum can be classified as alkanes, cycloalkanes, aromatics, polycyclic aromatics, asphaltines, and resins. Among the petroleum HCs, n-alkanes are the most amenable to biodegradation. Normally alkanes in the range of C5 to C10 are inhibitory to majority of the HC degraders at higher concentration as they disrupt lipid membrane when present as solvent. Alkanes in range of C20 to C40, also referred to as waxes, are less biodegradable as they being hydrophobic solids have low solubility in water. During degradation the alkanes are converted to alcohol by the action of oxygenase enzymes that attack the terminal methyl group. The alcohol is further oxidized to aldehyde and then to fatty acids. Further utilization of fatty acid occurs by $\beta$-oxidation of aliphatic chain. Higher the methyl branching lower is the extent of $\beta$-oxidation.

The cycloalkanes or alicyclic HCs are less degradable than alkanes. Here the biodegradability decreases with increase in number of ring structures. Alkyl substituted cycloalkanes can be degraded more easily as compared to nonsubstituted HCs. Cycloalkanes are degraded to cyclic alcohol by the action of oxidases which further is dehydrogenated to ketone. The primary products of metabolism of cycloalkanes are cycloketones and cycloalkane-carboxylic acids.

Mmom and Igbuku, (2015) reported that Biodegradable Contaminants such as crude oil soaked soil were treated by insitu and ex-situ (Engineered Bio cell) bioremediation techniques. Bioremediation, involved systematic tilling and application of microbial nutrient amendments- Contaminants at depths of $6 \mathrm{~m}$ to $10 \mathrm{~m}$ below ground surface were removed by deep excavation and treated by ex-situ process, Non-Biodegradable waste stream (burnt carbonized residue): These were handled through fixation and stabilization into cement blocks. About 40,000 blocks were produced, Oily-bituminous sludge: These were handled by Thermal desorption process.

Impacted Shallow Groundwater. Free phase oil on shallow groundwater trenches was removed by skimming of oil and application of bio-degrader to remove the oil.

Deep seated contaminated soil is being tackled by use of heavy equipment to excavate and remediate by either ex-situ bioremediation in an Engineered Bio cell or on-site ex-situ. Deep seated impacted soils with relatively light contaminants are excavated and remediated on-site in-situ using bioremediation process. Deep seated impacted soil with heavy contaminants is excavated and remediated using bioremediation process in an Engineered Bio cell. 


\section{Material and methods}

\subsection{Sample collection}

Samples were collected from an oil polluted site in Ejama-Ebubu Eleme Rivers state. The samples were taken from five spot (A-E), of depth 0-15 $\left(A_{1}-E_{1}\right)$ and 15-30 $\left(A_{2}-E_{2}\right)$ in sterile polyethylene bags, using appropriate equipment, then taken to the laboratory for analysis.

\subsection{Determination of physicochemical parameters of samples}

Physicochemical parameters such as $\mathrm{pH}$, nitrate, sulphate, phosphate, total petroleum hydrocarbon (TPH), poly aromatic hydrocarbon (PAH), salinity, temperature, conductivity and heavy metals (iron, zinc, nikel, lead, chromium) were determined.

\subsection{PH}

This test is done to determine the acidity or alkalinity of the sample site using Glass-electrode pH apparatus.

$20 \mathrm{~g}$ of soil sample was weighed out and sieved using a $2 \mathrm{~mm}$ sieve into a $50 \mathrm{~mL}$ beaker, $20 \mathrm{~mL}$ of distilled water was added and allowed to stand for 30 minutes and stirred occasionally with a glass rod.The pH probe was inserted into the partly settled suspension to measure the $\mathrm{pH}$.

\subsection{Nitrate}

Apparatus: B and L spectronic-20, electrophotometer.

Reagents: brucine $\left(2.5 \mathrm{~g}\right.$ of brucine dissolved in $100 \mathrm{~m} \mathrm{~L}$ of glacial acetic acid), conc. $\mathrm{H}_{2} \mathrm{SO}_{4}$, standard $\mathrm{NO}_{3}-\mathrm{N}$ solution, 50 ppm- $0.1805 \mathrm{~g}$ of $\mathrm{KNO}_{3}$ was dissolved in $500 \mathrm{~mL}$ of the extracting solution, $0.5 \mathrm{~mL}$ of chloroform as a preservative, dilute nitrate standard solution.

The Extraction solution-100g of sodium acetate was dissolved in $500 \mathrm{~mL}$ of distilled water and $30 \mathrm{~mL}$ of 99.58 acetic acid was added, then diluted to $1 \mathrm{~L} .5 .0 \mathrm{~g}$ of soil was transferred into a shaking bottle and $1 / 4$ teaspoon of activated carbon and $20 \mathrm{~m} \mathrm{~L}$ of extracting solutionwas added and shook for 1 minute then filtered. $1 \mathrm{~mL}$ aliquot of the soil extract was transferred to a vial and mixed, $0.5 \mathrm{~m} \mathrm{~L}$ of brucine reagent was added and then $2 \mathrm{~m} \mathrm{~L}$ of sulphuric acid the sample was mixed for 30 seconds and allowed to stand for 5 minutes. The sample was mixed again and $2 \mathrm{~mL}$ of distilled water added and mixing continued for about 30 seconds. The tubes were allowed to set in cold water for 15 minutes and transmittance was measured at $470 \mu$.

\subsection{Sulphate}

Reagent: $\mathrm{KH}_{2} \mathrm{PO}_{4}$ containing 500ppm P (extracting solution) $5 \mathrm{~g}$ of air-dried soil sample was weighed out and passed through a $2 \mathrm{~mm}$ sieve into a flask and $25 \mathrm{~m} \mathrm{~L}$ of extracting solution was added. The mixture was shake for 30 minutes on a mechanical shaker and centrifuged. The $\mathrm{SO}_{4}$ content was determined by turbidity.

\subsection{Phosphorous}

Apparatus: centrifuge, mechanical shaker, $20 \mathrm{~mL}$ test tube, B and L spectronic -electrophotometer.

Extracting solution- $15 \mathrm{~mL}$ of $1.0 \mathrm{~N} \mathrm{NH}_{4} \mathrm{~F}$ and $25 \mathrm{~m} \mathrm{~L}$ of $0.5 \mathrm{~N} \mathrm{HCl}$ was added to $460 \mathrm{~m} \mathrm{~L}$ distilled water, Stannous chloride $\left(\mathrm{SnCl}_{2}\right.$. $\left.2 \mathrm{H}_{2} \mathrm{O}\right)$ stock solution- $10 \mathrm{~g}$ of $\mathrm{SnCl}_{2}$. $2 \mathrm{H}_{2} \mathrm{O}$ was dissolved in $25 \mathrm{~mL}$ of conc. $\mathrm{HCl}$, Ammonium molybdate $\left(\mathrm{NH}_{4}\right)_{6} \mathrm{Mo}_{7} \mathrm{O}_{24} 4 \mathrm{H}_{2} \mathrm{O}-15 \mathrm{~g}$ of ammonium molybdate is dissolved in $350 \mathrm{~mL}$ of $10 \mathrm{~N} \mathrm{HCl}$ in a litre volumetric flask and cooled to room temperature then made up to $1 \mathrm{~L}$ with distilled water.

$1 \mathrm{~m} \mathrm{~L}$ of stock solution of stannous chloride was mixed with $333 \mathrm{~m} \mathrm{~L}$ of distilled water. $1 \mathrm{~g}$ of air dried soil sample was weighed and sieved with a $2 \mathrm{~mm}$ sieve into a $15 \mathrm{~mL}$ centrifuge tube and $7 \mathrm{~mL}$ of extracting solution was added. The mixture was shaked using a mechanical shaker and centrifuged at $2000 \mathrm{rpm}$ for 15 minutes. $2 \mathrm{~mL}$ of the clear supermatant was pipetted into a test tube. $5 \mathrm{~mL}$ of distilled water was added to $\left(\mathrm{NH}_{4}\right)_{6} \mathrm{Mo}_{7} \mathrm{O}_{24} .4 \mathrm{H}_{2} \mathrm{O}$ solution and mixed. $1 \mathrm{~m} \mathrm{~L}$ of $\mathrm{SnCl}_{2}$. $2 \mathrm{H}_{2} \mathrm{O}$ dilute solution was added and mixed. After 5 minute, the transmittance was measured on the electrophotometer at $660 \mathrm{~m} \mu$ wave length. 


\subsection{Determination of heavy metals}

\subsubsection{Soil pre-treatment}

$5 \mathrm{~g}$ of air dried soil sample was weighed out and sieved into a $100 \mathrm{~mL}$ flask using a $2 \mathrm{~mm}$ sieve, $2 \mathrm{ml}$ of $\mathrm{HNO}_{3}(\mathrm{aq})$ and $6 \mathrm{ml}$ of $\mathrm{HCl}_{(\mathrm{aq})}$ was added in the ratio of 1:3 to the already weighed sample. The mixture was digested by heating on a heating mantle until the sample attained near dryness to enable proper leaching of the sample. The sample was then diluted with distilled water and filtered using the watchman No. 42, 150mmin diameter filter paper into a $50 \mathrm{~mL}$ volumemetric flask. The filtrate was then made up to $50 \mathrm{~mL}$ mark. The atomic adsorption spectrometer (AAS) was calibrated using a standard solution for each of the metal of interest ( $\mathrm{Zn}-1$ and 2 ppm, Cr- 2 and 5 ppm, Pb- 0.5 and 1.0 ppm) The digested sample is then introduced into the AAS and the concentration of the metals were displayed.

\subsubsection{Determination of total petroleum hydrocarbon (TPH) and poly aromatic hydrocarbon (PAH)}

Residual total petroleum hydrocarbons (TPH) and polycyclic aromatic hydrocarbons (PAHs) were extracted from the samples and quantified using gas chromatograph-flame ionization detector (GC-FID).

\subsubsection{Extraction}

$2 \mathrm{~g}$ of sample was weighed into a clean extraction amber container. $10 \mathrm{~m} \mathrm{~L}$ of extraction solvent (pentane) was added into the sample and mixed thoroughly and allowed to settle. The mixture was carefully filtered into clean solvent rinsed extraction bottles using filter paper fitted into Buchner funnels. The extracts were concentrated to $2 \mathrm{~mL}$ and then transferred for separation.

\subsubsection{Separation}

$1 \mathrm{~cm}$ of moderately packed wool was placed at the bottom of $10 \mathrm{~mm}$ ID X $250 \mathrm{~mm}$ long chromatographic column. Slury of $2 \mathrm{~g}$ activated silica in $10 \mathrm{~mL}$ methylene chloride was prepared and placed into the chromatographic column. To the top of the column was added $0.5 \mathrm{~cm}$ of sodium sulphate. The column was rinsed with additional $10 \mathrm{~mL}$ o methylene chloride. The column was pre eluted with $20 \mathrm{~mL}$ of pentane, this was allowed to flow through the column at a rate of about 2 minutes until the liquid in the column was just above the sulphate layer, immediately, $1 \mathrm{~mL}$ of the extracted sample was transferred into the column. The extraction was rinsed with $1 \mathrm{~mL}$ of pentane and added to the column, the eluent was collected with graduated cylinder. Prior to exposure of the sulphate layer to air, pentane was added to the column in 1-2 mL increments accurately measured volume of 8-10 mL of the eluent was collected and was labelled aliphatics.

\subsubsection{Gas chromatographic analysis}

The concentrated aliphatic fraction were transferred into labelled glass vials with Teflon or rubber crimp caps for GC analysis, $1 \mu \mathrm{L}$ of the concentrated aliphatic fraction was injected by means of hypodermic syringe through a rubber septum into the column. Separation occurs as the vapour constituent partition of between the gas and liquid phases. The sample was automatically detected as it emerges from the FID whose response is dependent upon the composition of the vapour. The result was recorded.

\subsection{Bacterial enumeration}

\subsubsection{Enumeration of total heterotrophic bacteria (THB)}

The THB count was determined using the spread plate method on nutrient agar. The nutrient agar was prepared by dissolving $28 \mathrm{~g}$ of nutrient agar powder in $1000 \mathrm{~mL}$ of distilled water according to manufacturer's standard Soil suspensions were prepared by 10 -fold serial from each sample $1 \mathrm{~g}$ was homogenized in $9 \mathrm{ml}$ of $0.85 \%$ normal saline dilutions and then $10^{-4}$ and $10^{-5}$ dilution was spread on the plates in duplicates. The colony forming unit (CFU) of total heterotrophs was counted after incubation at room temperature for $24 \mathrm{hrs}$.

\subsubsection{Enumeration of hydrocarbon utilizing bacteria (HUB)}

The HUBs were enumerated using mineral salts medium (composition: $0.063 \mathrm{~g}$ of $\mathrm{NH}_{4} \mathrm{NO}_{3}, 0.19 \mathrm{~g}$ of $\mathrm{K}_{2} \mathrm{HPO}_{4}, 1.5 \mathrm{~g} \mathrm{OF}$ $\mathrm{NaCl}, 0.063 \mathrm{~g}$ of $\mathrm{MgSO}_{4}, 0.044 \mathrm{~g} \mathrm{OF} \mathrm{KCl}, 2.28 \mathrm{~g}$ of agar and $150 \mathrm{~mL}$ of distilled water) with crude oil as the sole source of carbon source. Hydrocarbon utilizing bacteria (HUB) were enumerated by a method adopted from (Hamamuraet al 2006) which involved the dilutions of appropriate sample suspensions and plating out on BushnellHaas agar from dilutions of $10^{-1}-10^{-3}$ in duplicates. Hydrocarbons were supplied through the vapour phase by placing sterile Whatman No.1 filter papers impregnated with crude oil on the lids of the inverted plates and incubated for 5 days at room 
temperature. Isolated colonies were further purified by sub-culturing and identified using biochemical tests and microscopy. Enumeration of THB and HUB was done every fort night.

\subsubsection{Purification and identification of hydrocarbon utilizing bacteria}

Discreet colonies of different HUB were randomly picked using a sterile inoculating wire loop and sub cultured by streaking on nutrient agar plates and incubated at $38^{\circ} \mathrm{C}$ for $24 \mathrm{~h}$. The purity of each colony was confirmed by Gram staining, the micro and macro morphological characteristics were recorded. Individual colonies were identified using the following biochemical tests: catalase and oxidase production, gas/acid production from fermentation of lactose, indole production, citrate utilization, triple sugar iron fermentation, and methyl red-VogesProskaeur.

\subsubsection{Gram's staining technique}

This test is differentiate between Gram positive and Gram negative bacteria species.

On clean grease free slides, one loopful of distilled water was placed and aseptically, a loopful of the subcultured organisms were smeared on different slides and allowed to air dry.The slides were heat fixed by passing through flame 5 times. The slides were stained with safranin for 1 minute and rinsed. The mordant Gram's iodine was added to the slide for 30 seconds and rinsed off, $75 \%$ ethanol was added and rinsed immediately. The secondary dye safranin was then added for 1 minute and rinsed. The slides were allowed to dry and viewed under the microscope.

\subsubsection{Catalase test}

Most bacterial have flavoprotein oxidases which produces $\mathrm{H}_{2} \mathrm{O}_{2}$, no $\mathrm{H}_{2} \mathrm{O}_{2}$ will be produced anaerobically since oxygen is absent to accept electrons. Peroxide is inhibitory to bacteria. Aerobes which are exposed to peroxide, normally possess catalase which decomposes peroxide to give water and oxygen gas, as in the eqation below:

\section{$2 \mathrm{H}_{2} \mathrm{O}_{2} \underset{2}{2} \mathrm{H}_{2} \mathrm{O}+\mathrm{O}_{2}$. Bubble formation is indicative of a positive result.}

On clean slides, hydrogen peroxide was dropped, each organism was asceptically smeared on hydrogen peroxide and observed for bubble formation, the results were recorded.

\subsubsection{Oxidase test}

Sterile filter paper was impregnated with oxidase reagent. Sterile wire loop was used to streak each organism on the filter paper. The streakings were observed for purple colour formation and the results were recorded.

\subsubsection{Citrate utilization test}

The citrate test uses a medium in which sodium citrate is the only carbon and energy source. In Simon's citrate agar, the $\mathrm{p} \mathrm{H}$ indicator is bromthymol blue, which is green at neutral $\mathrm{pH}$ and becomes blue when the medium becomes alkaline. If an organism can utilize citrate as the sole source of carbon and energy source, it will then need to use the ammonium salts for nitrogen source. This results in the release of ammonia, causing the $\mathrm{pH}$ to change to alkaline causing a colour change from green to royal blue.

$1.6 \mathrm{~g}$ of Simon citrate agar was dissolved in $70 \mathrm{~mL}$ of distilled water and heated to homogenize. the medium is then poured into Biju bottles and sterilized by autoclaving at. $121^{\circ} \mathrm{C}$, at $15 \mathrm{psi}$, for 15 minutes, the medium was then slanted to solidify. Aseptically the different isolates were inoculated into the medium by streaking on the slant and stabbing the butt. Then incubated at $38^{\circ} \mathrm{C}$ for $48 \mathrm{hrs}$ and observed for colour change.

\subsection{8. lactose fermentation (acid and gas production)}

$1 \mathrm{~g}$ of lactose broth was dissolved in $100 \mathrm{~m} \mathrm{~L}$ of distilled water.Bromocresol purple indicator was added to the broth.Durham's tubes were placed in test tubes and the lactose broth were added to the tubes amount enough to cover the Durhaam's tube and the tubes were sterilized by autoclaving at $121^{\circ} \mathrm{C}$, at 15 psi, for 15 minutes.Aseptically each isolate was inoculated in different tubes and incubated at $38^{\circ} \mathrm{C}$ for $48 \mathrm{hrs}$, each test tubes were observed for colour change and gas collection in the Durham's tube and the results recorded.

\subsubsection{Triple sugar iron agar (TSIA) test}

$3 \mathrm{~g}$ of TSIA was dissolved in $50 \mathrm{~mL}$ of distilled water and heated to homogenize. The medium was poured into test tubes and sterilized by autoclaving $121^{\circ} \mathrm{C}$, at $15 \mathrm{psi}$, for 15 minutes. The media was kept slanted and allowed to solidify. The 
test tubes were inoculated with the different isolates and incubated at $38^{\circ} \mathrm{C}$ for $48 \mathrm{hrs}$. The test tubes were then observed for changes and results were recorded.

\section{Results and discussion}

\subsection{Physiochemical parameter and heavy metals}

Table 1 Physiochemical parameter and heavy metals obtained from samples

\begin{tabular}{|l|l|c|c|}
\hline S/N & Parameters(s) & $\mathbf{A}_{\mathbf{1}}$ & $\mathbf{A}_{\mathbf{2}}$ \\
\hline 1 & $\mathrm{Ph}$ & 5.77 & 5.68 \\
\hline 2 & Conductivity $(\mu \mathrm{S} / \mathrm{cm})$ & 98 & 35 \\
\hline 3 & Nitrate $(\mathrm{mg} / \mathrm{kg})$ & 7.8 & 2.5 \\
\hline 4 & Phosphate $(\mathrm{mg} / \mathrm{kg})$ & 0.11 & 0.08 \\
\hline 5 & Sulphate $(\mathrm{mg} / \mathrm{kg})$ & 9 & 4 \\
\hline 6 & Iron, Fe $(\mathrm{mg} / \mathrm{kg})$ & 5715.3 & $5,923.5$ \\
\hline 7 & Zink, Zn $(\mathrm{mg} / \mathrm{kg})$ & 3.31 & 3.7 \\
\hline 8 & Nikel, Ni $(\mathrm{mg} / \mathrm{kg})$ & 1.06 & 2.22 \\
\hline 9 & Lead, Pb (mg/kg) & 4.12 & 2.86 \\
\hline 10 & Chromium, Cr $(\mathrm{mg} / \mathrm{kg})$ & 5.17 & 4.3 \\
\hline 11 & Vanadium $(\mathrm{mg} / \mathrm{kg})$ & 0.5 & 0.1 \\
\hline 12 & TPH $(\mathrm{mg} / \mathrm{kg})$ & 51.14 & 25.56 \\
\hline 13 & PAH $(\mathrm{mg} / \mathrm{kg})$ & 0.136 & 0.071 \\
\hline \multicolumn{2}{|l}{}
\end{tabular}

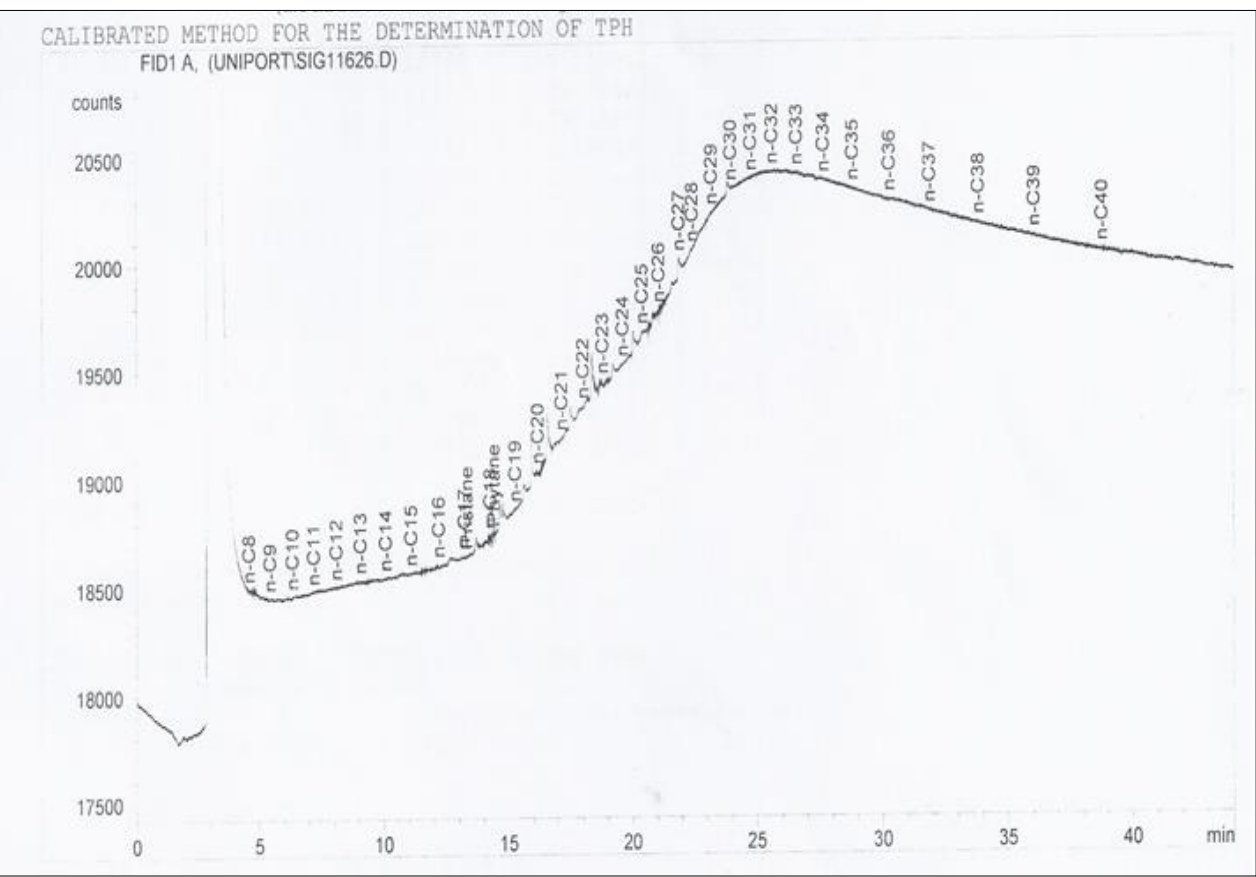

Figure 1 Total petroleum hydrocarbon for sample $A_{1}$ 
GSC Biological and Pharmaceutical Sciences, 2021, 17(02), 139-151

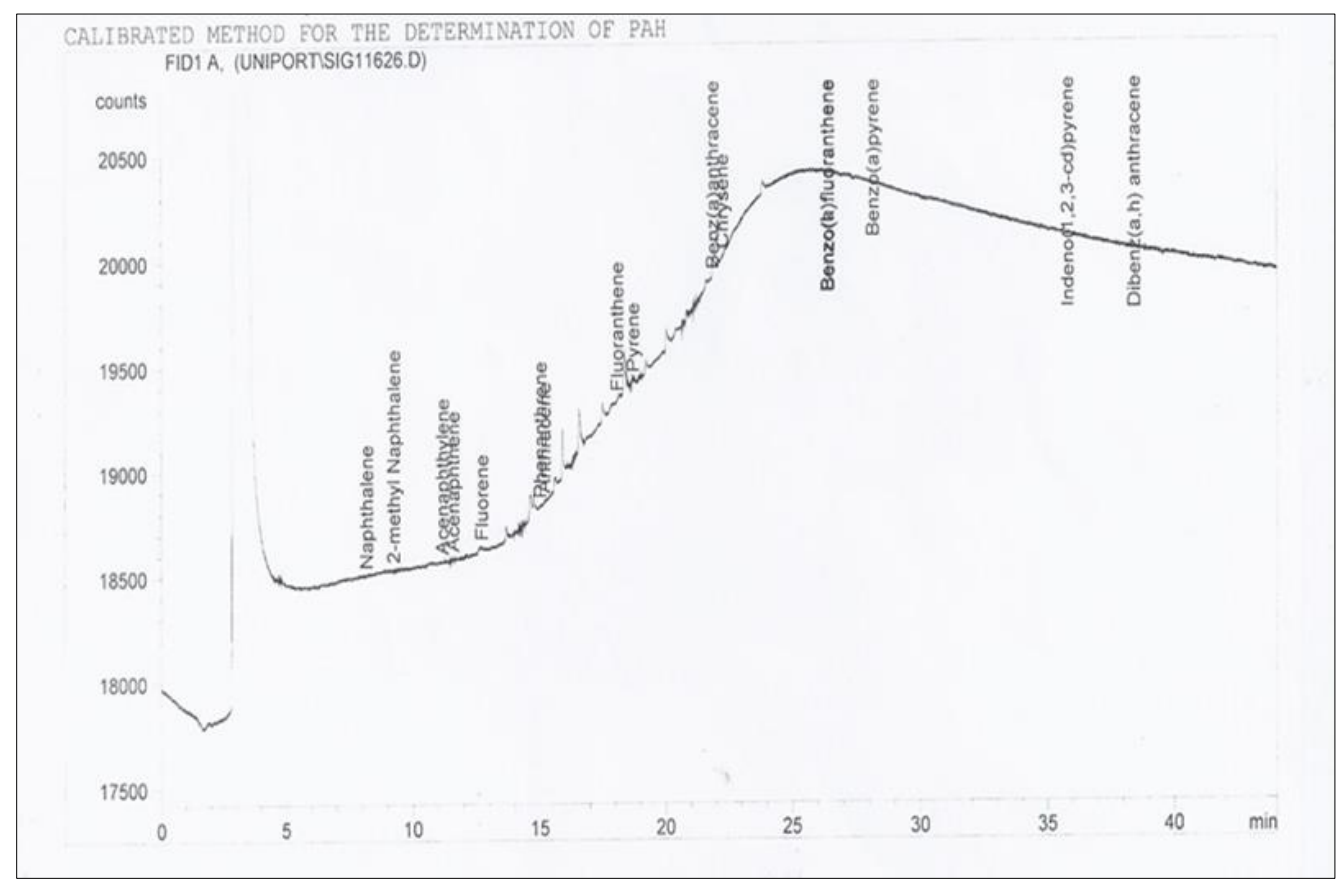

Figure 2 Poly aromatic hydrocarbon (PAH) for sample $A_{1}$

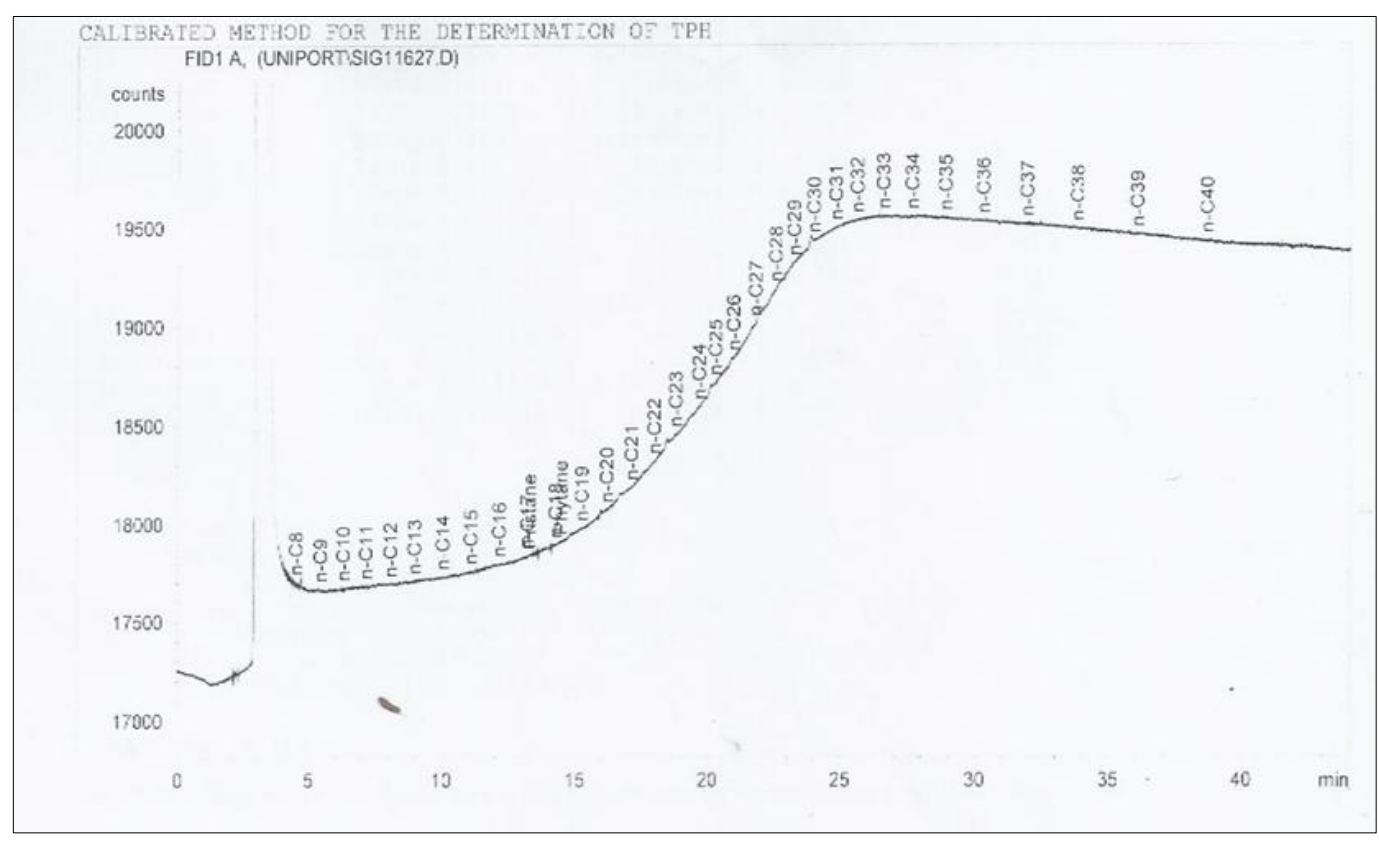

Figure 3 Total petroleum hydrocarbon for sample $A_{2}$ 
GSC Biological and Pharmaceutical Sciences, 2021, 17(02), 139-151

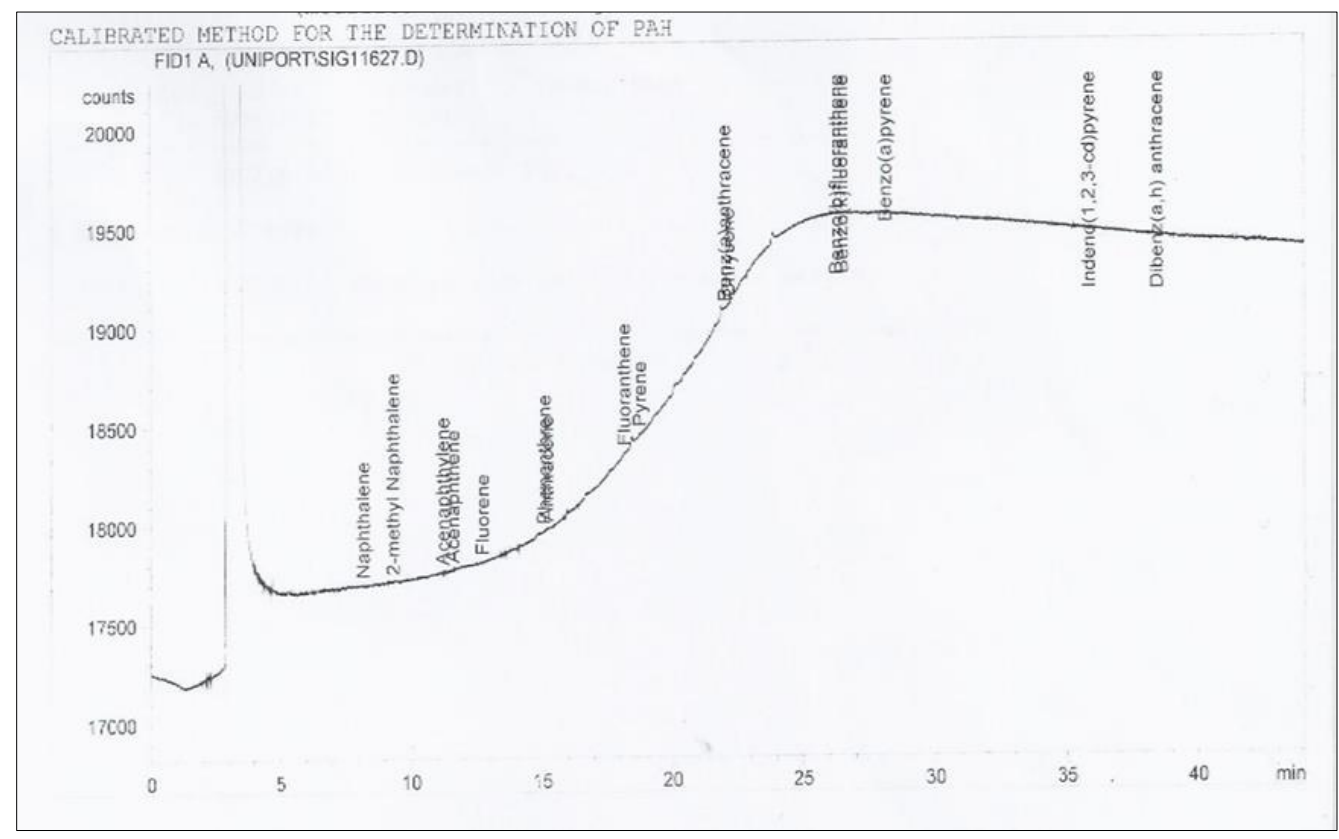

Figure 4 Poly aromatic hydrocarbon (PAH) for sample $\mathrm{A}_{2}$

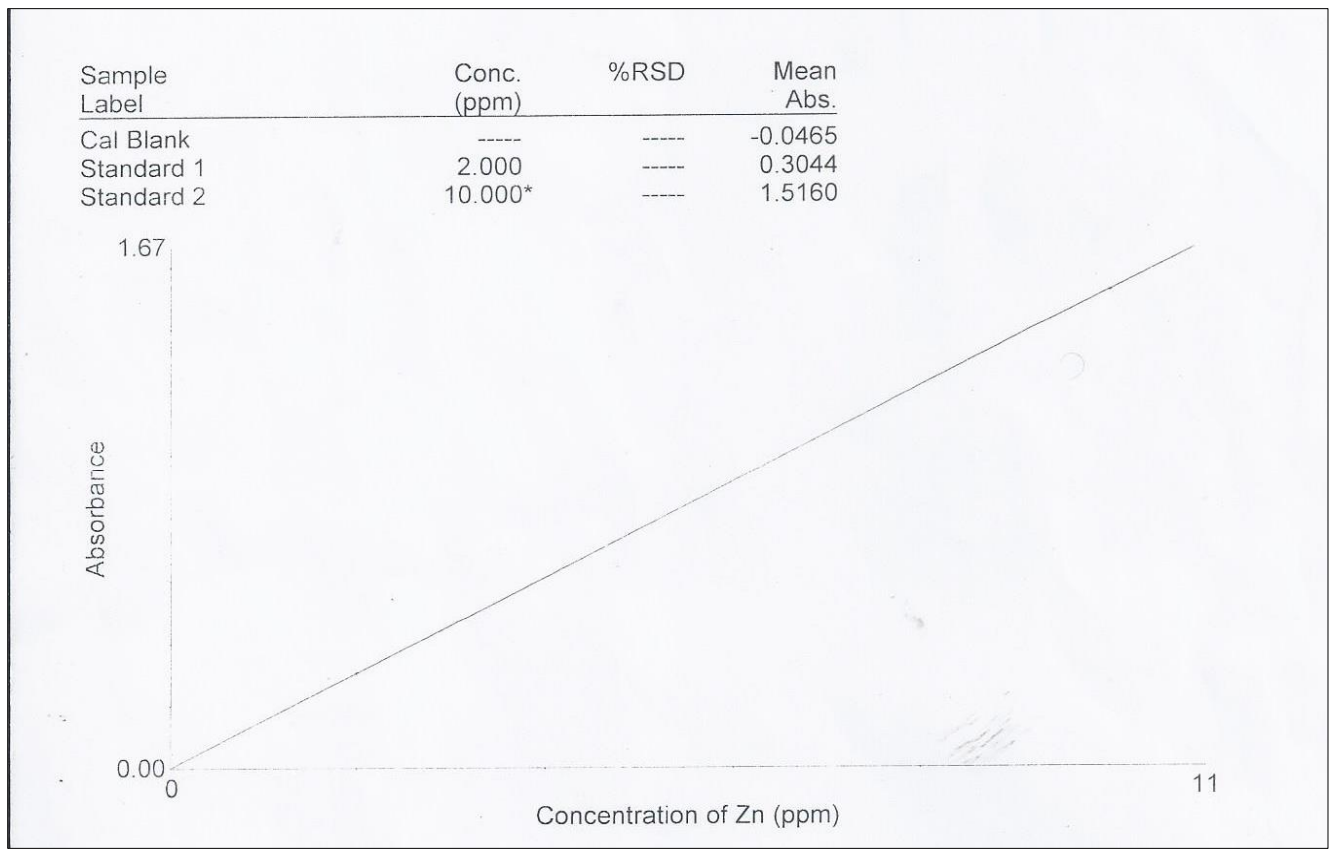

Figure 5 Concentration of $\mathrm{Zn}$ for sample $\mathrm{A}_{1}$ and $\mathrm{A}_{2}$ 
GSC Biological and Pharmaceutical Sciences, 2021, 17(02), 139-151

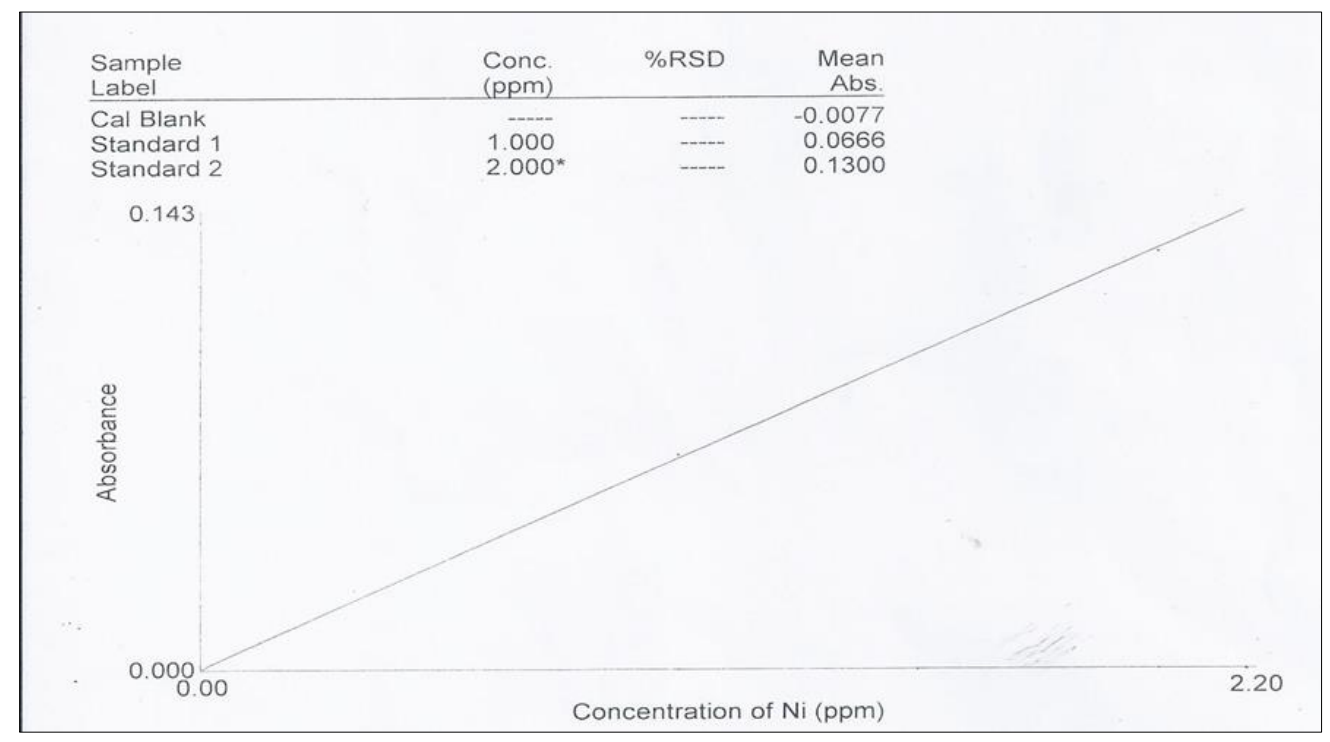

Figure 6 concentration of nitrogen for sample $A_{1}$ and $A_{2}$

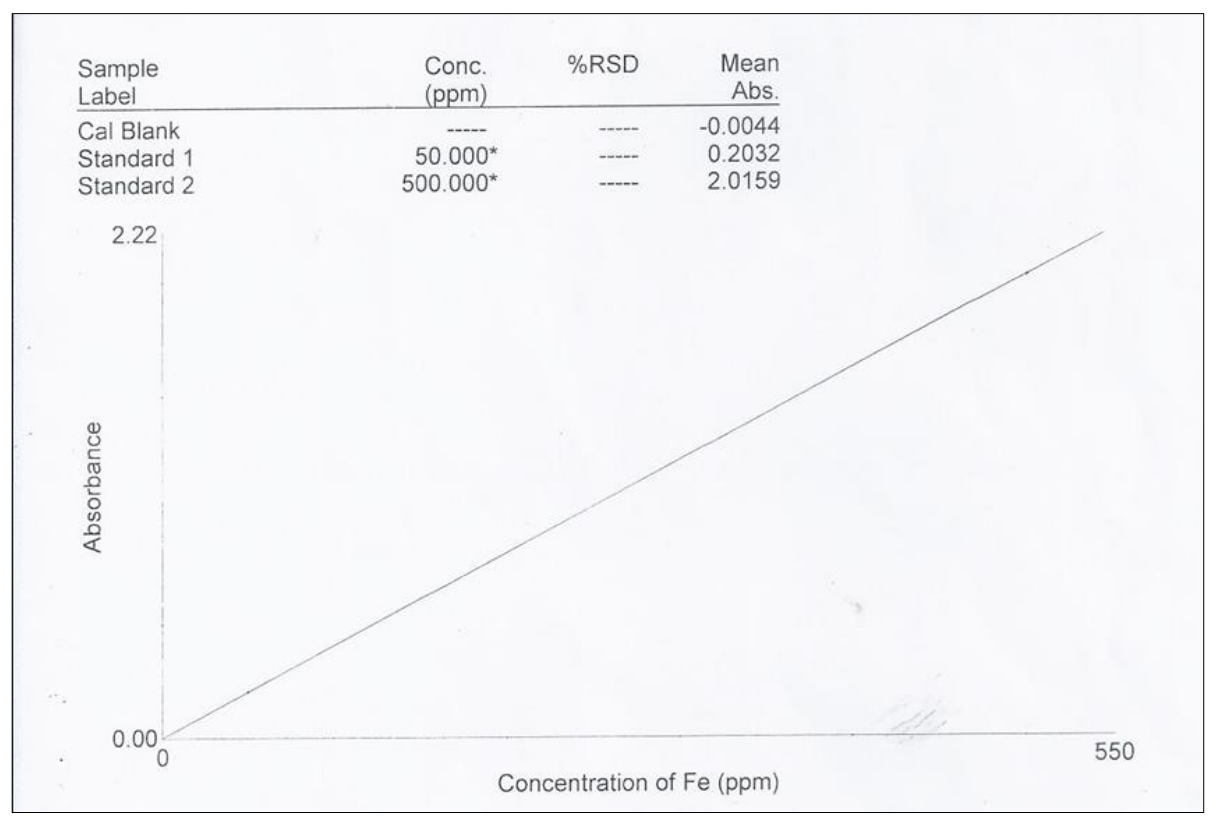

Figure 7 Concentration of iron for sample $A_{1}$ and $A_{2}$ 


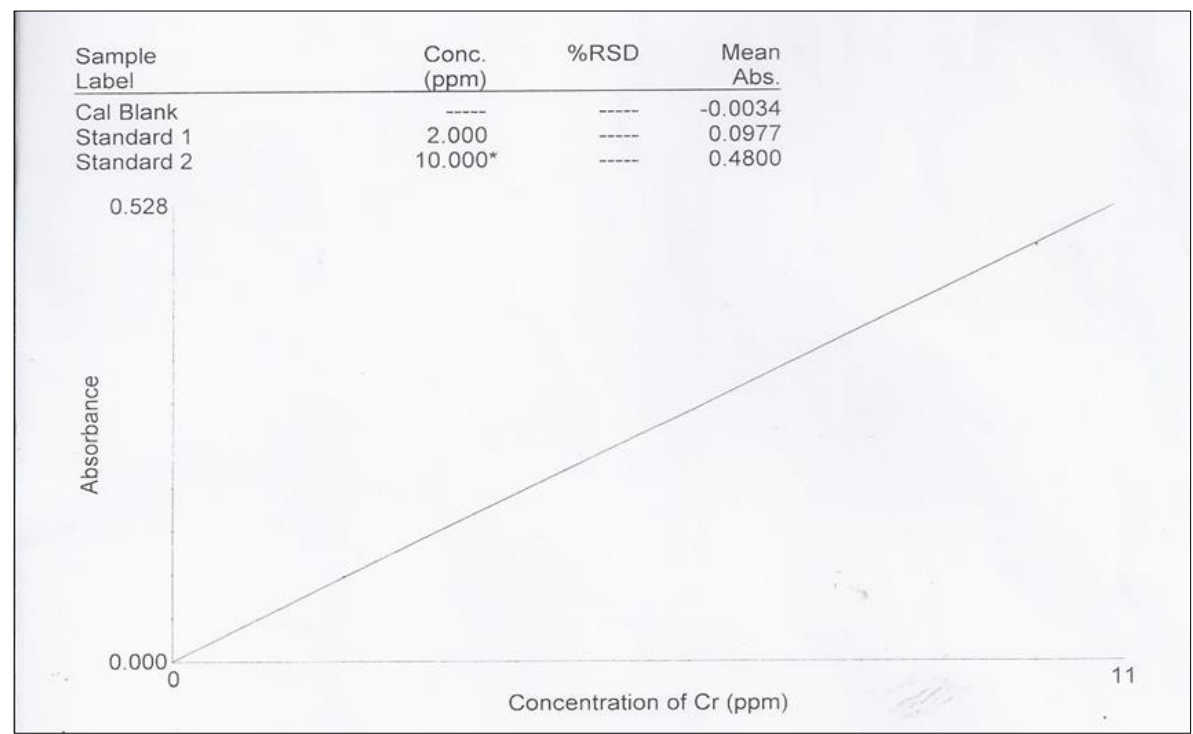

Figure 8 Concentration of chromium $\mathrm{Zn}$ for sample $\mathrm{A}_{1}$ and $\mathrm{A}_{2}$

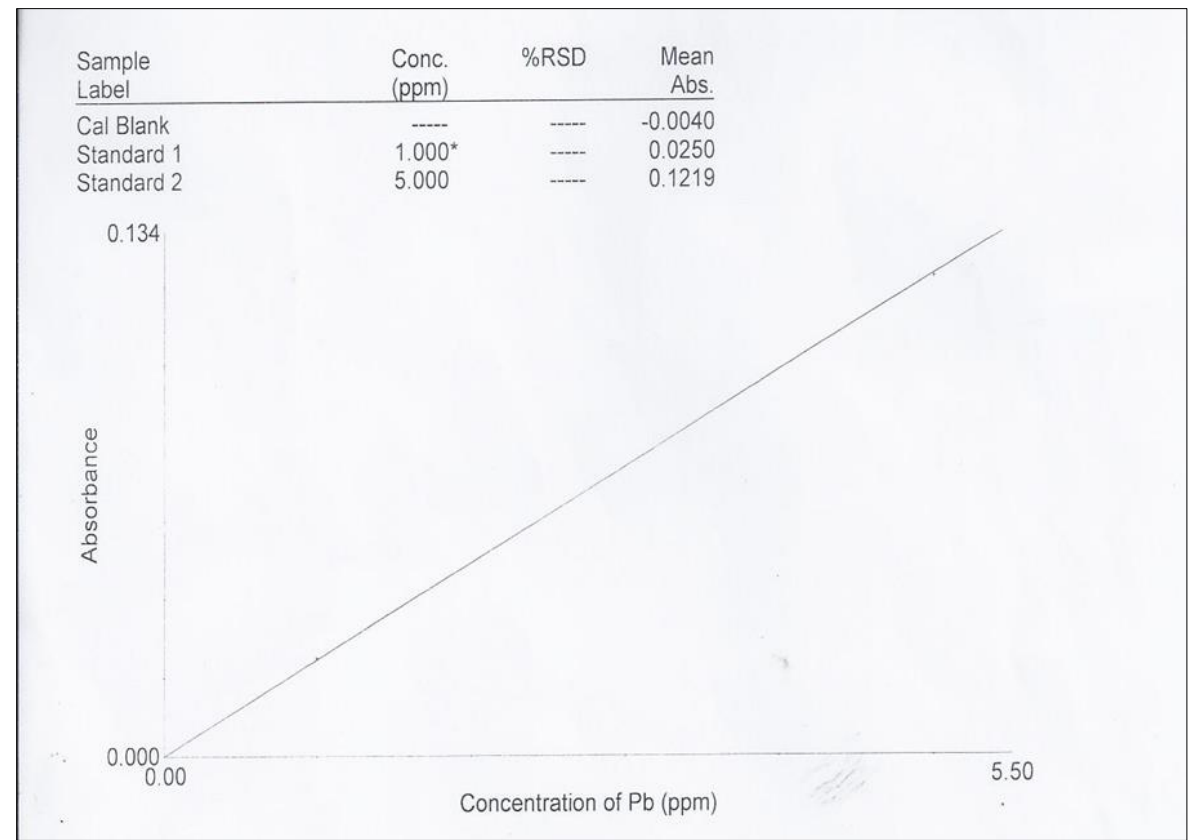

Figure 9 Concentration of lead for sample $A_{1}$ and $A_{2}$

\subsection{Bacterial enumeration}

After 24 hours of incubation for day 0- day 28 of isolation, the following results were obtained for THB as shown in table 2 below.

Soil, sediment and water physicochemical parameters are shown in Table 1. The parameters determined indicated that the samples had been exposed to hydrocarbon contamination.

These pollutants cause damages to humans and the ecosystem if not effectively remediated. The contamination may have resulted in the low pH of 5.77 depth $0-15 \mathrm{~cm}$ and 5.68 at depth $15-30 \mathrm{~cm}$ observed in soil. Nutrients are very important ingredients for successful biodegradation of hydrocarbon pollutants especially nitrogen, phosphorus and in some cases iron. Addition of nutrients is necessary to enhance biodegradation of crude oil pollutants (Chikereetal, 2014). 
Table 2 Total heterotrophic bacteria count obtained for all samples

\begin{tabular}{|l|c|c|c|c|}
\hline Nutrient agar (NA) & Sample & Dilution & Average & CFU/mL \\
\hline Day0 & $\mathrm{A}_{1}$ & $10^{-4}$ & 191 & $1.91 \times 10^{7}$ \\
\hline & & $10^{-5}$ & 100 & $1 \times 10^{8}$ \\
\hline & $\mathrm{A} 2$ & $10^{-4}$ & 76 & $7.6 \times 10^{6}$ \\
\hline Day 14 & & $10^{-5}$ & 40 & $4 \times 10^{7}$ \\
\hline & $\mathrm{A}_{1}$ & $10^{-4}$ & 116 & $1.16 \times 10^{7}$ \\
\hline & & $10^{-5}$ & 64 & $6.4 \times 10^{7}$ \\
\hline & $\mathrm{A} 2$ & $10^{-4}$ & 54 & $5.4 \times 10^{6}$ \\
\hline Day 28 & & $10^{-5}$ & 43 & $4.3 \times 10^{7}$ \\
\hline & $\mathrm{A} 1$ & $10^{-4}$ & 103 & $1.0310^{8}$ \\
\hline & & $10^{-5}$ & 61.5 & $6.15 \times 10^{7}$ \\
\hline & $\mathrm{A} 2$ & $10^{-4}$ & 34 & $3.4 \times 10^{6}$ \\
\hline & & $10^{-5}$ & 18 & $1.8 \times 10^{7}$ \\
\hline
\end{tabular}

The colonial morphology of each colony in pure culture is presented in colonial morphology of the isolates.Table $3 \& 4$

Table 3 Biochemical test result for the different isolates hydrocarbon utilizing bacteria

\begin{tabular}{|ll|ll|ll|ll|ll|ll|}
\hline$[1]$ & & {$[2]$} & Size(mm) & {$[3]$} & Transparency & {$[4]$} & Colour & {$[5]$} & Form & {$[6]$} & Elevation \\
\hline$[7]$ & Isolate 1 & {$[8]$} & 2.0 & {$[9]$} & Opaque & {$[10]$} & Cream & {$[11]$} & Entire & {$[12]$} & Umbonate \\
\hline$[13]$ & Isolate 2 & {$[14]$} & 0.5 & {$[15]$} & Opaque & {$[16]$} & White & {$[17]$} & Serrated & {$[18]$} & Flat \\
\hline$[19]$ & Isolate 3 & {$[20]$} & & {$[21]$} & Opaque & {$[22]$} & White & {$[23]$} & Entire & {$[24]$} & Umbonate \\
\hline$[25]$ & Isolate 4 & {$[26]$} & 1 & {$[27]$} & Transparent & {$[28]$} & Cream & {$[29]$} & Serrated & {$[30]$} & Flat \\
\hline$[31]$ & Isolate 5 & {$[32]$} & 3 & {$[33]$} & Transparent & {$[34]$} & Cream & {$[35]$} & Entire & {$[36]$} & Unbonate \\
\hline$[37]$ & Isolate 6 & {$[38]$} & 2 & {$[39]$} & Opaque & {$[40]$} & Cream & {$[41]$} & Entire & {$[42]$} & Unbonate \\
\hline$[43]$ & Isolate 7 & {$[44]$} & 1 & {$[45]$} & Translucent & {$[46]$} & Green & {$[47]$} & Entire & {$[48]$} & Flat \\
\hline$[49]$ & Isolate 8 & {$[50]$} & 2 & {$[51]$} & Opaque & {$[52]$} & Cream & {$[53]$} & Entire & {$[54]$} & Flat \\
\hline$[55]$ & Isolate 9 & {$[56]$} & 1 & {$[57]$} & Transparent & {$[58]$} & & {$[59]$} & Entire & {$[60]$} & Flat \\
\hline$[61]$ & Isolate 10 & {$[62]$} & 1 & {$[63]$} & Transparent & {$[64]$} & Green & {$[65]$} & Entire & {$[66]$} & Flat \\
\hline
\end{tabular}

The presence of microbial activity was determined by the enumeration of culturable total heterotrophic bacteria and hydrocarbon utilizing bacteria as presented in Table 1 and 2 respectively. It was observed that the Ejama-Ebubu sample contained THB count ranging from $1.8 \times 10^{7}-1.19 \times 10^{7} \mathrm{CFU} \mathrm{mL} \mathrm{mL}^{-1}$ and a mean HUB count of $9 \times 10^{3}-1.3 \times 10^{4} \mathrm{CFU}_{\mathrm{mL}}$ 1. This site is continuously exposed to petroleum hydro-carbons owing to navigational activities and this may have enriched the sediment with hydrocarbon utilizing bacteria. However, the fewness in number of the HUB counts may be attributed to the inadequacy of nutrients at that depth especially nitrogen and phosphorus which deplete with input of hydrocarbons. The Gram negative bacteria belonging to the genus pseudomonas is the most frequent. Other genera isolated wereNocardia, Micrococcus,Chromobacterium, Burkholdia, Corynebacterium. After every forth night, the bacterial count reduces, this may be due to depletion of available nutrient in the soil sample. 
Table 4.5 also indicates that the crude oil aerobic degradative ability of the individual bacterial isolates was significant as evidenced by turbidity and emulsification of $1 \mathrm{ml}$ of crude oil in $100 \mathrm{ml}$ of Bushnell-Haas broth after 14days incubation when compared with the test isolates on day zero incubation. Bacteria that are capable of utilizing hydrocarbons as energy and carbon sources in broth culture have been shown to produce bioemulsifiers or biosurfactants that assist in the transport of hydrocarbons into the cell via efficient uptake systems (Atlaset al 2005).

Table 4 Biochemical test result for the different isolates hydrocarbon utilizing bacteria

\begin{tabular}{|c|c|c|c|c|c|c|c|c|c|c|c|c|c|c|}
\hline & \multirow[b]{2}{*}{ Gram's reaction } & \multirow[b]{2}{*}{$\frac{5}{5}$} & \multirow{2}{*}{$\frac{\tilde{s}}{\tilde{J}}$} & \multirow[b]{2}{*}{$\xi$} & \multirow[b]{2}{*}{$s$} & \multirow{2}{*}{ 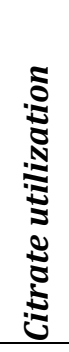 } & \multicolumn{2}{|c|}{ 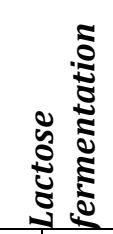 } & \multirow[b]{2}{*}{$\frac{\mathfrak{s}}{\delta}$} & \multicolumn{4}{|l|}{$\overleftarrow{5}$} & \multirow[b]{2}{*}{$\begin{array}{l}\text { Probable } \\
\text { Organism }\end{array}$} \\
\hline & & & & & & & $\mathbf{A}$ & Gas & & 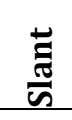 & $\underset{\Xi}{E}$ & $\stackrel{N}{\mathbf{I}}$ & $\tilde{J}$ & \\
\hline Isolate 1 & Gram negative rod & - & + & + & - & - & + & - & - & B & A & - & + & Escherichia coli \\
\hline Isolate 2 & Gram positive rod & + & + & - & + & - & - & - & + & A & B & - & - & Norcardia $s p$. \\
\hline Isolate 3 & Gram negative rod & + & + & + & - & - & + & + & - & B & B & - & - & Burkholderia sp. \\
\hline Isolate 4 & Gram positive rod & - & + & - & + & - & + & - & - & B & B & - & - & Corynebacterium sp. \\
\hline Isolate 5 & Gram positive cocci & - & + & - & + & + & + & - & - & B & B & - & - & Micrococcus \\
\hline Isolate 6 & Gram negative rod & - & - & - & + & + & - & - & - & B & A & - & + & Chromobacterium sp. \\
\hline Isolate 7 & Gram negative rod & + & - & - & - & + & - & - & - & B & B & - & - & Pseudomonas sp. \\
\hline Isolate 8 & Gram positive cocci & - & + & - & + & + & + & - & - & B & B & - & - & Micrococcus coli \\
\hline Isolate 9 & Gram negative rod & - & + & + & - & - & + & - & - & B & A & - & + & Pseudomonas sp. \\
\hline Isolate 10 & Gram negative rod & + & - & - & - & + & - & - & - & B & B & - & - & Pseudomonas sp. \\
\hline
\end{tabular}

\section{Conclusion}

This show the presence of petroleum hydrocarbons in the Ejama_Ebubu site as well as known genera of hydrocarbon utilizing bacteria. The biases associated with culture-dependent microbial enumeration techniques may limit the full description of the bacterial diversity in Ejama-Ebubu site. From the study, it is concluded that microorganisms that can degrade hydrocarbons are found in oil contaminated soil and can easily be isolated from these contaminated sites, although it is very difficult to work with aromatic hydrocarbons due to their volatility and toxic effects.

Pseudomonas sp. Isolate 7, 9, Burkholderia sp. Isolate 2, showed appreciable aerobic degradative ability of hydrocarbons, while isolates 1,5 , and 6 showed little emulsication of the crude oil, this could imply that this isolates are unable to degrade hydrocarbon under aerobic condition. Bacterial strains capable of degrading complex hydrocarbons present in the environment have a potential to be used as an effective tool for removing ecotoxic compounds.

\section{Compliance with ethical standards}

\section{Acknowledgment}

We Acknowledge to John, G.N.

\section{Disclosure of conflict of interest}

No Conflict of interest. 


\section{References}

[1] Tlas RM, Philp J. Bioremediation: applied microbial solutions for real-world environmental cleanup. American Society for Microbiology (ASM) Press. 2005; 78-105.

[2] Chauhan A, Rahman F, John G, Oakeshott, Jain RK. Bacterial metabolism of polycyclic aromatic hydrocarbons: strategies for bioremediation. Review of Indian Journal of Microbiology. 2008; 48: 95-113.

[3] Chaillana F, Flècheb A, Burya E, Phantavonga Y-hui, Saliot A, Oudot J. Identification and biodegradation potential of tropical aerobic hydrocarbon-degrading microorganisms. Res. Microb. 2004; 155(7): 5.

[4] Chaineau CH, Yepremian C, Vidalie JF, Ducreux J, Ballerini D. Bioremediation of a crude oil-polluted soil: biodegradation, leaching and toxicity assessments. Wat. Air. Soil. Poll. 2003; 144: 419.

[5] Chikere CB, Okpokwasili GC, Chikere BO. Monitoring of microbial hydrocarbon remediation in the soil. Biotechnology. 2011; 1: 117-138.

[6] Daane LL, Harjono I, Zylstra GJ., Haggblom MM. Isolation and characterization of polycyclic aromatic hydrocarbon degrading bacteria associated with the rhizosphere of salt marsh plants. Applied and Environmental Microbiology. 2001; 67(6): 2863-2691.

[7] Gogoi BK, Dutta NN, Goswami P, Mohan TR. A case study of bioremediation of petroleum-hydrocarbon contaminated soil at a crude oil spill site. Adv. Environ. Res. 2003; 7:767.

[8] Hamamura N, Olson S, Ward D, Inskeep W. Microbial population dynamics associated with crude-oil biodegradation in diverse soils. Appl Environ Microbial. 2006; 72:6316-6324.

[9] Mmom, Prince, Igbuku, Augustine. Challenges and Prospect of Environmental Remediation/Restoration in Niger Delta of Nigeria: The Case of Ogoniland. Journal of Energy Tehnology and Policy. 2015; 5: 1-4.

[10] NalineeKumari, Abhishek Vashishtha, Pooja Saini, EktaMenghani. Isolation, Identification and Characterization of Oil Degrading Bacteria Isolated from the Contaminated Sites of Barmer, Rajasthan. International Journal of Biotechnology and Bioengineering Research. 2013; 4: 429-434.

[11] Sebiomo A, Bankole SA,Awosanya AO. Determination of the ability of microorganisms isolated from mechanic soil to utilise lubricating oil as carbon source. Afr. J. Microbiol. Res. 2010; 4(21): 2257-2264.

[12] Spence JM, Bottrell SH, Thornton SF, Richnow HH, Spence KH. Hydrochemical and isotopic effects associated with petroleum fuel biodegradation pathways in a chalk aquifer. J. Contam. Hydrol. 2005; 79: 67.

[13] Varjani SJ, Rana DP, Bateja S, Upasani VN. Isolation and Screening for Hydrocarbon Utilizing Bacteria (HUB) from Petroleum Samples. Int.J.Curr.Microbiol.App.Sci. 2013; 2(4): 48-60.

[14] Vieira PA, Vieira RB, Franca FP, Cardoso VL. Biodegradation of effluent contaminated with diesel fuel and gasoline. J. Hazard. Mat. 2007; 140(1 2): 5259.

[15] Watanabe K. Current Opinion in Biotechnology. 2001; 12: 237-241. 